УДК:930.2:394.4:17.023(477) “17”

\author{
Ласкава Ю. В. \\ кандидат філологічних наук, \\ старший викладач
}

Державного вищого навчального закладу «Запорізький національний університет»

\title{
ОСТАННІ СИМВОЛИ ДУХОВНОСТІ КОЗАЦЬКОЇ ДЕРЖАВНОСТІ - ГЕТЬМАН КИРИЛО РОЗУМОВСЬКИЙ І КОШОВИЙ ПЕТРО КАЛНИШЕВСЬКИЙ
}

Стаття присвячена дослідженню діяльності Кирила Розумовського та Петра Калнишевського в контексті висвітлення історичного періоду занепаду козаччини. $У$ статті за допомогою історичних джерел та художніх творів українських письменників розглядаються постаті останнього козацького гетьмана та кошового, здійснюється спроба зіставної характеристики циих діячів.

Ключові слова: останній гетьман, останній кошовий, козак, історичні джерела.

Статья посвящена исследованию деятельности Кирилла Разумовского и Петра Калнышевского в контексте освещения исторической эпохи упадка казачества. В статье с помощью исторических источников и художественных произведений украинских писателей рассматриваются фигуры последнего казаикого гетмана и кошевого, осуществляется попытка сопоставимой характеристики этих деятелей.

Ключевые слова: последний гетман, последний кочевой, казак, исторические источники.

The article is devoted to research of Cyril Razumovsky and Peter Kalnyshevsky coverage in the context of the historical period of decline Cossacks. The article by using historical sources and artistic works by Ukrainian writers considered figures of last Cossack hetman and last koshovjy, attempts to comparable characteristics of these figures.

Keywords: last hetman, the last koshovjy, Cossacks, historical sources.

В останні десятиліття відзначається тенденція до збільшення кількості досліджень історичної спадщини України та українців, відбуваються чисельні розвідки з теми занепаду козацького періоду.

Під критичним поглядом науковців опинились останній гетьман козацької державності Кирило Розумовський та останній кошовий Запорозької Січі Петро Калнишевський. Інтерес до цих постатей є цілком виправданим, адже дослідження їх діяльності допомогло б краще усвідомити та виокремити ті причини, які сприяли занепаду козаччини, як явища. 
Висвітлення питання аналізу цих історичних постатей знайшло своє детальне відображення в багатьох історичних документах, в художній літературі та усній народній творчості. Варто відзначити праці таких дослідників та літературознавців як С. Авдеєнко, О. Апанович, М. Аркас, М. Грушевський, Я. Новицький, О. Струкович, Д. Яворницький; Р. Іваничук, М. Ільницький, А. Кащенко, Г. Колісник, Д. Кулиняк, В. Лоташевський, М. Слабошпицький та ін.

Метою статті $\epsilon$ дослідження внутрішньої та зовнішньої політики К. Розумовського та П. Калнишевського. Здійснено спробу зіставного аналізу їх діяльності. Особливу увагу приділено аналітичній характеристиці символізму, закладеного в даній історичній епосі та у двох останніх козацьких державотворцях.

Правління Кирила Розумовського та Петра Калнишевського припало на важкі та буремні часи української держави. Після смерті гетьмана Павла Полуботка, Російська імперія поширила свій тиск на території України. Намагаючись утримати владу, вона заборонила козакам обирати гетьмана.

Певний час гетьманством керувала Малоросійська колегія, а згодом Правління гетьманського уряду. Таким чином колись виборча посада гетьмана, стала реалізацією намісництва Російської імперії. Середина XVIII ст. стала рушійною для української гетьманської держави. Уряд на чолі з імператрицею Єлизаветою видає указ «Про буття в Малоросії гетьманові за колишніми звичаями». Таким чином, цей документ докорінно змінив ситуацію в України та вже у 1750 році на чолі гетьманату став Кирило Розумовський.

Прийнято вважати, що своєю посадою Кирило завдячує братові Олексію Розумовському, який був фаворитом імператриці та здійснював вагомий вплив на іiі рішення, про що згадує В. Лоташевський у своєму творі про П. Калнишевського “Останній отаман. Царська інтрига”: “Колись він був таємно повінчаний із царицею, тому ци поводився вільно [Лоташевський 2009:19]”. Проте варто відзначити, що Кирило мав особливу повагу серед 
козацьких старшин завдяки своєму розуму. Багато подорожуючи Свропою, він спрямував свій досвід на розбудову гетьманату.

Як і Кирило Розумовського, Петро Калнишевський користувався повагою козацьких старшин та рядових козаків та виборював свою посаду, в той самий час, коли Петро I намагався вибороти українські землі. За всю історію існування Запорозької Січі він найдовше був на найголовнішій посаді і керував у надзвичайно складний для усієї України час. Ось як описує Р. Іваничук у своєму творі “Журавлиний крик” призначення П. Калнишевського кошовим: «Козацька сірома кидала шапки на честь нового отамана на січовому майдані коло Покровської цееркви» [Іваничук 2001: 27]. Це все супроводжується демонстрацією думок щодо Калниша: «... Прийде, мовляв, Калниш - буде на столі книш» [Іваничук 2001: 30], «А Калниш - дбалещ̧ь» [Іваничук 2001: 30] (козак Скирта). Тут бачимо в «згорнутому» вигляді практично весь той спектр оцінок, який залишився в історії щодо фігури останнього кошового.

Кирило Розумовський розпочав свою діяльність 3 відновлення козацьких вольностей. Спираючись на думку освічених козацьких старшин, він запропонував ідею реорганізації устрою Гетьманщини. Посада гетьмана мала б стати спадковою за родиною Розумовських. Було також запропоновано створити головний керуючий орган - Генеральні Збори.

К. Розумовському вдалось зменшити ролі загальновійськової ради, зміцнивши старшинську раду, військову канцелярію та військовий суд, а результатом цих дій стало утворення централізованого адміністративного управління на території України. Продовжуючи свою діяльність, гетьман швидко почав роздавати землі козацьким старшинам, таким чином перетворюючи їх на поміщиків і привчаючи до осілого способу життя.

Подібну лінію поведінки у своїй діяльності дотримувався і П. Калнишевський. Кошовий може розраховувати на підтримку громади, тому що має свою політичну програму, за умови реалізації якої постає надія на те, що припиниться чи стане не такою інтенсивною серія заходів царського уряду по заселенню території вольностей колоністами та російськими військовими у 
фортецях: «- Шаблею і ралом, братове! Бо чим стала Україна? Гарнізоном. Тож треба, щоб вона отримала всі державні чинники: господарство, торгівлю, рільнищтво, ремесло, а ні, то нас проковтне кріпащтво, $і$ військо наше муситиме захищати його» [Іваничук, 2001: 32].

Д. Кулиняк, як і багато дослідників, значне місце приділяє зусиллям кошового по заселенню території Вольностей як однієї з першооснов ставлення до його історичної діяльності: «Завдяки його турботам у дикому степу виростали нові села. Так, зокрема, виникло ц село Петриківка на Дніпропетровщині, назване на честь кошового. Він, як міг, старався вести самостійну політику, в міру можливості уникаючи конфронтації з изаризмом» [Кулиняк 2005: 17].

Наслідком його зусиль стало виникнення на Запорожжі 45 сіл, більше 4 тисяч хуторів-зимівників, у яких до 1775 року було поселено близько 50 тисяч хліборобів. 3 першого року свого отаманства Петро Калнишевський наполягав на осілості козаків, щоб не тільки численні гурти козацьких коней, корів, овець бродили по цих благодатних степах, але щоб козаки створювали власне господарство й сім'ю, ставали землеробами.

Дуже показовим у цьому сенсі $є$ крок, що його здійснив кошовий отаман в останній рік існування Нової Січі, пославши А. Головатого до Петербурга 3 проханням перетворити Запорожжя на територію $з$ тим же статусом і тією ж автономною організацією, що й у Донського козачого війська. Д. Кулиняк відстоює тезу про те, що П. Калнишевський є все ж діячем-державником, через що й постраждав від Катерини II. Але це побіжно деконструює інший міф: про те, що останній кошовий - жертва й мученик, тому що покараний як прихований сепаратист, хоча й із перевищенням міри покарання.

Територіальні питання межували 3 питанням адміністративноуправлінського характеру. Кирило Розумовський під час свого правління надзвичайно опікувався судовим питанням. Була проведена судова реформа, в наслідок якої було створено ряд нових судів - громадський, земський, а також підкоморський. 
Незважаючи на величезні досягнення останнього гетьмана та кошового у внутрішньо-територіальних питаннях, провідним лейтмотивом їх діяльності стало освітянське питання. Здобуваючи освіту в Європі, Кирило Розумовський не здобув славу в якості військового. Всі свої зусилля він поклав на покращення соціального стану Гетьманщини. Почалась активна розбудова Глухова та Батурина, зведено велику кількість палаців, було заплановано будівництво університету в Батурині, відкрито першу музичну школу у Глухові, в якому активно приймали участь селяни.

Велику допомогу отримала від К. Розумовського Києво-Могилянська академія. За його сприяння в академії впроваджуються реформаторські правила, які дозволили осучаснити, і як результат, спростити весь навчальний процес. На території університетів розвивалось книгодрукування. I зважаючи на той факт, що друкарство в цілому мало незадовільний стан, відкриття таких друкарень здійснило значний поштовх в розвитку освіти та культури.

За часів гетьманування Кирила Розумовського докорінних змін зазнала також релігійна сфера. Всі служби велись російською мовою, в проповідях не лунали а ні національні інтереси, а ні визвольні ідеї. К. Розумовський домігся заборони висвячення чужинців в ієрархи i запропонував повернутись до традиційного висвячення. Це значно зменшило вплив церкви на економічну та соціальну сфери.

П. Калнишевський дбав, щоб демократичні та гуманні принципи, які склалися в системі освіти Запорожжя, не порушувалися, оберігав національний характер школи, любові до рідного народу, його культури, віри, звичаїв. Навчання велося на Запорожжі рідною тогочасною українською мовою. «П. І. Калнишевський дбав про Січову школу $i$ школи в паланках, сприяв розвитку запорозької музичної иколи, хору, оркестру, а також народного ремесла і живопису, який тепер називається петриківським» [ІЗК 1990: 55].

Ще одним напрямом діяльності кошового було будівництво церков. Власним коштом Калнишевського було збудовано ряд православних храмів: св. Петра й Павла в Межигірському монастирі під Києвом, Покрова Пресвятої 
Богородиці у Ромнах, храми в Лохвиці i Петриківці. «Не шкодував [П. Калнищевський] громей $і$ на иерковні книги, начиння та одяг» [Струкович 2000: 274].

П. Калнишевський - амбівалентна історична фігура, що принципово не дає виносити однозначні вироки. В потрактуванні роману Г. Колісника «Полин чорний, мак гіркий» кошовий є однією з визначальних фігур української історії, адже П. Калнишевський показав шлях подальшого розвитку суспільства насамперед засобами накопичення матеріальних чинників усамостійнення України, чим «переграв» план Російської імперії поглинути Південну Україну в проекті «Новоросії». Той факт, що Новоросія - це лише історичний анахронізм, а колишнє Дике Поле увійшло в межі України - це значною мірою й історична заслуга останнього кошового, що пожертвував собою заради цього грядущого.

Отже, Кирило Розумовський та Петро Калнишевський - надзвичайно помітні історичні постаті, які досі викликають багато питань. Останній гетьман та останній кошовий Запорозької Січі здійснили вагомий вплив на розвиток гетьманської України. Провідною лінією їх діяльності стало збереження традиційних цінностей українського народу. Символічним $є$ й той факт що ці вони покинули життя в один рік, завершивши собою період «золотої осені» козаччини.

\section{БІБЛІОГРАФІЯ}

Авдеенко 1995 - Авдеенко С. Последний атаман: Повести и очерки из истории Таврического края / С. И. Авдеенко. - Мелитополь, 1995. - 69 с.

Апанович 1993 - Апанович О. Останній кошовий Запорозької Січі / О. М. Апанович // Гетьмани України i кошові отамани Запорозької Січі / О. М. Апанович. - К. : Либідь, 1993. - С. 254-272.

Іваничук 2001 - Іваничук Р. Журавлиний крик: [роман] / Р. Іваничук. К. : ТАСТ-М, 2001. - 384 с. - (Історія України в романах)

Ільницький 1989 - Ільницький М. М. Людина в історії: [сучасний історичний роман] / М. М. Ільницький. - К.: Дніпро, 1989. - 356 с. 
ІЗК 1990 - Історія запорозького козацтва: сучасний етап та проблеми вивчення / М. П. Ковальський, Ю. А. Мицик, А. Г. Болебруха та ін.Дніпропетровськ: Тов-во “Знання” УРСР, 1990. - 60 с.

Кулиняк 2005 - Лицар Дикого поля. Останній кошовий отаман Запорозької Січі Петро Калнишевський та його доба / Д. І. Кулиняк. - К. : Варта, 2005. - 143 c.

Лоташевський 2009 - Лоташевський В. Останній отаман. Царська інтрига / В. П. Лоташевський. - К. : Факт, 2009. - 224 с.

Струкович 2000 - Струкович О. Петро Калнишевський / О. Струкович // Історія України в особах. Козаччина. - К. : Україна, 2000. - С. 269-276. 